Article

\title{
Exoproduction and Molecular Characterization of Peroxidase from Ensifer adhaerens
}

\author{
Ayodeji Falade ${ }^{1,2,3, *} \mathbb{C}$, Atef Jaouani ${ }^{4}$, Leonard Mabinya ${ }^{1,2}$, Anthony Okoh ${ }^{1,2}$ and \\ Uchechukwu Nwodo ${ }^{1,2}$ \\ 1 SAMRC Microbial Water Quality Monitoring Centre, University of Fort Hare, Private Bag X1314, \\ Alice 5700, South Africa \\ 2 Applied and Environmental Microbiology Research Group (AEMREG), Department of Biochemistry and \\ Microbiology, University of Fort Hare, Private Bag X1314, Alice 5700, South Africa \\ 3 Department of Biochemistry, University of Medical Sciences, Ondo 351101, Nigeria \\ 4 Laboratory of Microorganisms and Active Biomolecules, Faculty of Sciences of Tunis, \\ University of Tunis El Manar, Tunis 2092, Tunisia \\ * Correspondence: afalade@unimed.edu.ng
}

Received: 20 May 2019; Accepted: 25 June 2019; Published: 1 August 2019

Featured Application: This paper determined the culture conditions for optimal peroxidase production by Ensifer adhaerens NWODO-2, which are necessary for large-scale production. Moreover, utilization of agricultural residues as cheap renewable substrates by the bacteria would be a cost-effective means of peroxidase production.

Abstract: The increased industrial application potentials of peroxidase have led to high market demand, which has outweighed the commercially available peroxidases. Hence, the need for alternative and efficient peroxidase-producers is imperative. This study reported the process parameters for enhanced exoperoxidase production by Ensifer adhaerens NWODO-2 (accession number: KX640918) for the first time, and characterized the enzyme using molecular methods. Peroxidase production by the bacteria was optimal at $48 \mathrm{~h}$, with specific productivity of $12.76 \mathrm{U}$ $\mathrm{mg}^{-1}$ at $\mathrm{pH} 7,30^{\circ} \mathrm{C}$ and $100 \mathrm{rpm}$ in an alkali lignin fermentation medium supplemented with guaiacol as the most effective inducer and ammonium sulphate as the best inorganic nitrogen source. Upon assessment of some agricultural residues as sources of carbon for the enzyme production, sawdust gave the highest peroxidase productivity $\left(37.50 \mathrm{U} \mathrm{mg}^{-1}\right)$ under solid-state fermentation. A search of the polymerase chain reaction (PCR)-amplified peroxidase gene in UniProtKB using blastx showed $70.5 \%$ similarity to an uncharacterized protein in Ensifer adhaerens but phylogenetic analysis suggests that the gene may encode a catalase-peroxidase with an estimated molecular weight of approximately $31 \mathrm{kDa}$ and isoelectric point of about 11. The nucleotide sequence of the detected gene was deposited in the GenBank under the accession number MF374336. In conclusion, the ability of the strain to utilize lignocellulosic materials for peroxidase production augurs well for biotechnological application as this would greatly reduce cost, which is a major challenge in industrial enzyme production.

Keywords: catalase-peroxidase; microbial enzyme; peroxidase; polymerase chain reaction; proteobacteria

\section{Introduction}

Peroxidases are oxidative enzymes with the capacity to oxidize several recalcitrant compounds. They are characterized by several biotechnological potentials spanning different industries including 
textiles, paper and pulp, chemicals, water and cosmetics [1,2]. However, the industrial applications of peroxidases are hindered by high production cost, poor yield $[3,4]$ and enzyme instability due to increased concentration of hydrogen peroxide [5].

Given the diverse application potentials of peroxidases, increased demand is inevitable. This has, therefore, necessitated the search for organisms with improved extracellular peroxidase production capacity. Over the years, fungi have been the most efficient producers of peroxidases [6-8]. Nevertheless, some bacteria, largely actinobacteria, have also shown potential for peroxidase production [9-12]. Peroxidases are also found in other living organisms but occur intracellularly and are produced in minute quantity. Exoproduction of peroxidase is advantageous over the intracellular production as the purification and recovery of an exoenzyme is simplified while the isolation and purification of an intracellular enzyme is costly, complex and time-consuming [12]. Furthermore, the interest in microbial peroxidases has continued to increase as microbial enzymes seem to be more stable than enzymes of plant and animal origin [13].

Ligninolytic bacteria hold a great potential for peroxidase production. Lignin degradation activities of these organisms are accompanied in particular by exoproduction of lignin-modifying enzymes (LMEs), predominantly peroxidases, as secondary metabolites. These enzymes can easily be harvested and exploited for various biotechnological applications.

Ensifer adhaerens NWODO-2 (KX640918) is a lignin-degrading bacterial strain recently isolated by the authors [14]. It belongs to the class: alpha-proteobacteria, one of the few classes of bacteria with lignin-degradation activities $[15,16]$. The whole-genome sequencing of Rhizobium sp. strain YS-1r, a lignin-degrading alpha proteobacteria, revealed the presence of a gene encoding the expression of dye-decolourizing peroxidase [17], an extracellular LME. Moreover, gene prediction analysis revealed the expression of 6 putative peroxidase genes in a Klebsiella sp. strain BRL 6-2 [18], a ligninolytic gamma proteobacteria. Furthermore, production of peroxidase by another proteobacteria, Pseudomonas species, has been reported [19]. It is clear that proteobacteria is an emerging ligninolytic bacteria with enormous potential for the production of LMEs including peroxidases. Our preliminary screening has revealed the peroxidase production potential of Ensifer adhaerens NWODO-2 [14]. This study, therefore, seeks to determine the culture parameters for optimal exoperoxidase production by Ensifer adhaerens NWODO-2 and characterize the enzyme using molecular approaches.

\section{Materials and Methods}

\subsection{Isolation of Ligninolytic and Peroxidase-Producing Bacteria}

The bacteria was isolated from a Tyhume River (Geograhical coordintes: $32^{\circ} 46^{\prime} \mathrm{S}$ and $26^{\circ} 51^{\prime} \mathrm{E}$ ) sample by an enrichment method, with the use of alkali lignin as sole carbon source [20]. Thereafter, the organism was selected based on its lignin-degrading activity and peroxidase production potential [14]. The sequence analysis of the 16S rRNA gene of the organism indicated 99\% similarity to Ensifer adhaerens S4-6 (KY496256) as reported in our previous study [14].

\subsection{Exoperoxidase Production under Submerged Fermentation (SMF)}

Peroxidase was produced under submerged fermentation as described in our previous study [14] using an alkali lignin medium (ALM) comprising the following: $\mathrm{K}_{2} \mathrm{HPO}_{4}\left(4.55 \mathrm{~g} \mathrm{~L}{ }^{-1}\right), \mathrm{KH}_{2} \mathrm{PO}_{4}$ $\left(0.53 \mathrm{~g} \mathrm{~L}^{-1}\right), \mathrm{MgSO}_{4}\left(0.5 \mathrm{~g} \mathrm{~L}^{-1}\right), \mathrm{NH}_{4} \mathrm{NO}_{3}\left(5 \mathrm{~g} \mathrm{~L}^{-1}\right)$, yeast extract $\left(0.1 \mathrm{~g} \mathrm{~L}^{-1}\right)$ and $0.1 \%$ w/v alkali lignin (Sigma-Aldrich, Pretoria, South Africa). Briefly, the fermentation medium was aseptically inoculated with $2 \%$ bacterial suspension (Optical density @ $600 \mathrm{~nm} \approx 0.1$ ) and then incubated at $30{ }^{\circ} \mathrm{C}$ and $140 \mathrm{rpm}$ for $48 \mathrm{~h}$, the period at which peroxidase activity was initially detected during the qualitative screening [14]. Subsequently, cultures were withdrawn and centrifuged at 10,000 $\mathrm{g}$ and the supernatant was used as crude enzyme for the determination of peroxidase activity. The enzyme production was carried out in triplicate, with the tests run at the same time. All the medium components except alkali lignin were sourced from Merck KGaA, Darmstadt, Germany. 


\subsection{Determination of Peroxidase Activity}

The enzyme activity was determined according to the method of Chance and Maehly [21], with some modifications reported in our previous study [14]. Briefly, about $25 \mu \mathrm{L}$ of crude enzyme was added to a mixture containing $5 \% w / v$ pyrogallol (substrate) and $0.1 \mathrm{M}$ potassium phosphate buffer ( $\mathrm{pH}$ 6.0). The reaction was initiated by $0.5 \% v / v \mathrm{H}_{2} \mathrm{O}_{2}(30 \% w / w)$ and the linear increase in absorbance at $420 \mathrm{~nm}$ was examined for $1 \mathrm{~min} 42 \mathrm{~s}$ using a SynergyMx 96-well microplate reader (BioTek Instruments, Winooski, VT, USA). The reaction mixture without crude enzyme was used as the blank. In this study, a unit of peroxidase activity was defined as the amount of enzyme required for oxidation of $1 \mu$ mole of pyrogallol to purpurogalin in $34 \mathrm{~s}$.

\subsection{Determination of Process Parameters for Optimal Exoperoxidase Production}

The process parameters for optimal exoperoxidase production were assessed using the method reported by Fatokun et al. [22] with some modifications. The initial $\mathrm{pH}$ for optimal exoperoxidase production was evaluated by growing Ensifer adhaerens NWODO-2 in an ALM with the initial pH ranging from 3 to 11 at $30^{\circ} \mathrm{C}$. Thereafter, the optimum incubation temperature was determined by growing the test bacteria at different temperatures, ranging from 20 to $45^{\circ} \mathrm{C}$ in the same fermentation medium with $\mathrm{pH} 7$, being the optimal initial $\mathrm{pH}$ for exoperoxidase production by the bacteria. Then, the influence of agitation speed on exoproduction of peroxidase was assessed by cultivating the test organism in the fermentation medium at predetermined conditions $\left(30^{\circ} \mathrm{C}, \mathrm{pH} 7\right)$ and different agitation rates: 0 to $200 \mathrm{rpm}$.

Furthermore, the impact of lignin monomers on exoproduction of peroxidase was assessed by growing Ensifer adhaerens NWODO-2 in an alkali lignin fermentation medium augmented with $1 \mathrm{mM}$ of various lignin monomers: guaiacol, veratryl alcohol, vanillin, vanillic acid and ferulic acid [12] using the following optimal parameters for the enzyme production: temperature $\left(30^{\circ} \mathrm{C}\right)$, initial $\mathrm{pH}$ (7) and agitation speed (100 rpm). The alkali lignin medium without supplementation was used as control. Subsequently, the test bacteria was grown in the production medium, wherein the nitrogen source was augmented with varied inorganic nitrogen (ammonium nitrate, ammonium chloride and ammonium sulphate) at the predetermined optimal conditions for exoperoxidase production $\left(30^{\circ} \mathrm{C}\right.$,

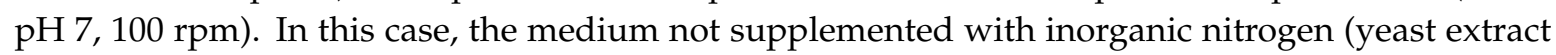
only) served as the control. All the experiments were done in three replicates.

\subsection{Exoperoxidase Production Over a Time Course}

The exoperoxidase production by Ensifer adhaerens NWODO-2 and its cell growth were evaluated over $144 \mathrm{~h}$ using the optimized process parameters determined in this study. The supernatant recovered from the culture was assayed for exoperoxidase and non-peroxide dependent exoenzyme production every $24 \mathrm{~h}$ [23]. Also, the total concentration of protein was estimated according to the method of Bradford [24] as reported earlier in our recent study [25]. Then, the bacterial growth was determined by the optical density at $600 \mathrm{~nm}$.

\subsection{Utilization of Agricultural Residues for Exoperoxidase Production}

Some agricultural residues (sawdust, wheat straw and corn stover) obtained from Alice metropolis, South Africa, were utilized for exoperoxidase production using solid state fermentation (SSF). The residues were prepared as described by Falade et al. [25] and, subsequently, were utilized as substrates for exoperoxidase production using the method described by Neifar and coauthors [26] with slight modifications reported in our previous study [25].

\subsection{Polymerase Chain Reaction (PCR) Detection of Peroxidase Gene}

DNA was extracted from the pure culture of Ensifer adhaerens NWODO-2 using boiling method [27] as described in our previous study [28]. The extracted DNA was used for the 
polymerase chain reaction (PCR), which was performed in a thermocycler (G-STORM, Essex, UK) with the following primers, designed using primer premier version 5.0 and synthesized by Inqaba Biotech, South Africa (Forward: 5'-CGACCCTGCCTACGAAAAGAT-3' and Reverse: $5^{\prime}$-ATAGTTGCGGAAGCCCTCGGA-3'). The following PCR conditions: initial denaturation at $95^{\circ} \mathrm{C}$ (5 min); denaturation at $94{ }^{\circ} \mathrm{C}(1 \mathrm{~min})$; annealing at $58^{\circ} \mathrm{C}(1 \mathrm{~min})$; extension at $72{ }^{\circ} \mathrm{C}(1 \mathrm{~min})$ for 35 cycles and final extension at $72{ }^{\circ} \mathrm{C}(5 \mathrm{~min})$ were used. The amplified product was electrophoresed in $1.5 \%$ agarose gel and viewed under ultraviolet (UV) trans-illuminator. Thereafter, the PCR product was subjected to Sanger dideoxy sequencing analysis, then, the nucleotide sequence was searched in UniProt Knowledgebase and PeroxiBase database using the blastx program.

\subsection{Bioinformatics Analysis}

The deduced protein sequence of Ensifer adhaerens NWODO-2 and selected bacterial peroxidases from PeroxiBase were analyzed using bioinformatic tools. The phylogenetic analysis was conducted using the neighbour-joining method [29] in MEGA 7.0 software [30] while the physicochemical properties (molecular weight and isoelectric point) were determined by Geneious 10.2.2 (Biomatters, Ltd., Auckland, New Zealand).

\subsection{Data Analysis}

Data, where appropriate, were subjected to one-way analysis of variance (ANOVA) followed by Tukey's Multiple Comparison Test using Graph Pad Prism 7.0 [28] (Graph Pad Software Inc., San Diego, CA, USA). Significance was accepted at $p \leq 0.05$.

\subsection{Accession Number}

The gene sequence reported in the current study is accessible in the National Centre for Biotechnology Information (NCBI) repository with accession number: MF374336.

\section{Results and Discussion}

\subsection{Determination of Process Parameters for Optimal Exoperoxidase Production}

The utility of peroxidase in different industrial sectors has led to an increased demand, which in the near future may not be met by horseradish peroxidase (HRP), the major commercially available peroxidase. Hence, the need for novel sources of peroxidase, particularly bacteria because they are more efficient, they grow faster, and can easily be modified genetically [14]. This study optimized extracellular peroxidase production by Ensifer adhaerens NWODO-2 through determination of the process parameters (medium $\mathrm{pH}$, incubation temperature and agitation speed), which are significant for optimal growth and metabolic activities of an organism and amending the composition of the production medium. Bacterial growth has been linked to constant production of extracellular enzymes [12,31,32]. Hence, factors capable of influencing bacteria growth such as $\mathrm{pH}$, temperature and agitation as well as the composition of the medium will invariably play an important part in enzyme secretion by the bacteria.

The $\mathrm{pH}$ of the cultivation environment significantly influences the electric charge of the microbial cell, consequently affecting the absorption of nutrients and intracellular enzymatic activities [33,34]. The effect of initial medium $\mathrm{pH}$ on exoperoxidase production by Ensifer adhaerens NWODO-2 is presented in Figure 1a. The results showed that peroxidase production by the test strain, Ensifer adhaerens NWODO-2 within $\mathrm{pH} 5-9$ was significantly different $(\mathrm{F}=123.7, p$ value $=p<0.0001$ for ANOVA). According to Tukey's test, however, peroxidase production at $\mathrm{pH} 5\left(2.92 \pm 0.14 \mathrm{U} \mathrm{mL}^{-1}\right)$ and $\mathrm{pH} 8\left(3.03 \pm 0.32 \mathrm{U} \mathrm{mL}^{-1}\right)$ was not significantly different. In this study, maximum peroxidase production was observed at an initial $\mathrm{pH} 7\left(5.83 \pm 0.00 \mathrm{U} \mathrm{mL}^{-1}\right)$; peroxidase activity was not observed at $\mathrm{pH} 3,4,10$ and 11 (Figure 1a). This finding agrees with the works of Rob et al. [35] and Nour El-Dein et al. [36], in which maximum peroxidase production by Streptomyces avermitilis UAH30 and Streptomyces sp. K37 was achieved at pH 7 and 7.5, respectively. However, Musengi et al. [12] observed 
optimum peroxidase production by Streptomyces sp. BSII\#1 at $\mathrm{pH} 8$ while we recorded $\mathrm{pH} 5$ as the optimal $\mathrm{pH}$ for peroxidase production by Raoultella ornithinolytica $\mathrm{OKOH}-1$ in a recent study [25]. It is worthy of note that the characteristic production of peroxidase by the test bacteria at a neutral $\mathrm{pH}$ augurs well for biotechnological applications as the large volume of acid and base required for $\mathrm{pH}$ adjustment would be saved [37], consequently, reducing the cost of peroxidase production.
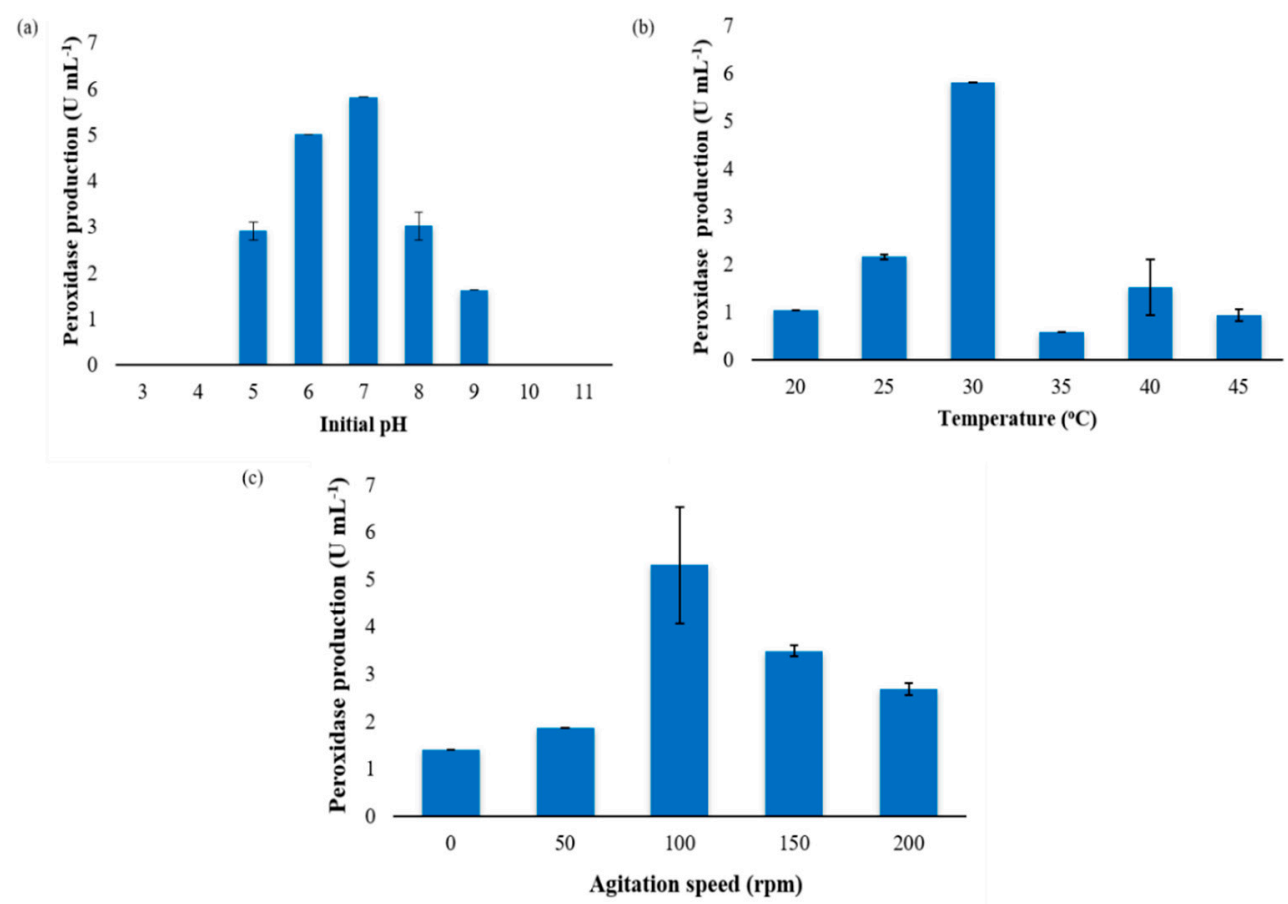

Figure 1. Determination of process parameters for optimal exoperoxidase production by Ensifer adhaerens NWODO-2. (a). Initial medium $\mathrm{pH}$. ANOVA: $\mathrm{F}=123.7, p$ value $=p<0.0001, p$ value summary $=* *$ (highly significant), $\mathrm{R}$ squared $=0.9900 .(\mathrm{b})$ Incubation temperature. ANOVA: $\mathrm{F}=63.44, p$ value $=$ $p<0.0001, p$ value summary $={ }^{* * *}$ (highly significant), $\mathrm{R}$ squared $=0.9814$. (c) Agitation speed. Analysis of variance (ANOVA): $\mathrm{F}=7.760, p$ value $=0.0226, p$ value summary $={ }^{*}$ (significant), $\mathrm{R}$ squared $=0.8613$.

The effect of incubation temperature on exoperoxidase production by Ensifer adhaerens NWODO-2 is shown in Figure $1 \mathrm{~b}$. The results revealed that peroxidase production differs significantly $(\mathrm{F}=63.44$, $p$ value $=p<0.0001$ for ANOVA) across the investigated temperatures: $20-45{ }^{\circ} \mathrm{C}$, with optimum production recorded at $30^{\circ} \mathrm{C}\left(5.83 \pm 0.00 \mathrm{U} \mathrm{mL}^{-1}\right)$. Nonetheless, Tukey's multiple comparison test showed there was no significant difference in the enzyme production at $20^{\circ} \mathrm{C}\left(1.05 \pm 0.00 \mathrm{U} \mathrm{mL}^{-1}\right)$, $35^{\circ} \mathrm{C}\left(0.58 \pm 0.00 \mathrm{U} \mathrm{mL}^{-1}\right), 40{ }^{\circ} \mathrm{C}\left(1.52 \pm 0.59 \mathrm{U} \mathrm{mL}^{-1}\right)$ and $45^{\circ} \mathrm{C}\left(0.94 \pm 0.12 \mathrm{U} \mathrm{mL}^{-1}\right)$. Although there is no previous report on optimal temperature for exoperoxidase production by Ensifer species, our finding agrees with the result obtained by Rajkumar et al. [38], where optimal peroxidase production by a Bacillus sp. was also observed at $30^{\circ} \mathrm{C}$. Nevertheless, Rao and Kavya [39] and Musengi et al. [12] recorded $37^{\circ} \mathrm{C}$ as the temperature for optimum production of peroxidase by Bacillus subtilis and Streptomyces sp. BSII\#1, respectively, whereas Falade et al. [25] reported $35^{\circ} \mathrm{C}$ as the temperature for optimal exoperoxidase activity by Raoultella ornithinolytica $\mathrm{OKOH}-1$. The reason for the inconsistencies in the optimal temperature for peroxidase production by the different bacteria species is unclear. However, all the temperatures that supported maximum peroxidase production by the various organisms are in the mesophilic range [25]. The decline in the enzyme production by Ensifer adhaerens NWODO-2 observed at temperatures lower and higher than $30^{\circ} \mathrm{C}$ (Figure $1 \mathrm{~b}$ ) may probably be due to decrease in metabolic activities, which consequently, may inhibit the organism growth and enzyme biosynthesis [40]. 
Nutrient accessibility by microorganisms is influenced by agitation, which improves aeration and enhances appropriate mixing of nutrients during fermentation [41]. The influence of agitation rate on exoperoxidase production by Ensifer adhaerens NWODO-2 as presented in Figure 1c revealed that peroxidase production under static condition and across all the studied agitation speeds (50-200 rpm) differ significantly $(\mathrm{F}=7.760, p$ value $=0.0226$ for ANOVA), with the optimal production recorded at $100 \mathrm{rpm}\left(5.31 \pm 1.23 \mathrm{U} \mathrm{mL}^{-1}\right)$. Nevertheless, the difference between peroxidase production at 150 $\mathrm{rpm}\left(3.50 \pm 0.12 \mathrm{U} \mathrm{mL}^{-1}\right)$ and $200 \mathrm{rpm}\left(2.69 \pm 0.12 \mathrm{U} \mathrm{mL}^{-1}\right)$ was not significant (Tukey's test). This finding shows that peroxidase production by Ensifer adhaerens NWODO-2 was affected by agitation as there was a significant increase in peroxidase production at $100 \mathrm{rpm}\left(5.31 \pm 1.23 \mathrm{U} \mathrm{mL}^{-1}\right)$ when compared with static condition $\left(1.4 \pm 0.00 \mathrm{U} \mathrm{mL}^{-1}\right)$. This result is in agreement with previous similar studies, where agitation affected the level of enzyme production [22,42,43]. In this study, $100 \mathrm{rpm}$ was the most favourable agitation speed for peroxidase secretion by the test organism but Patil [43] reported $180 \mathrm{rpm}$ as the agitation rate that supported optimal lignin peroxidase production by Bacillus megaterium. The decrease in peroxidase production observed at 150 and $200 \mathrm{rpm}$ in this study may be as a result of foaming or shearing stress on the mycelium.

Although the report on the induction of peroxidases by lignin monomers in bacteria is limited, there are quite a number of studies on the inductive effect of lignin monomers on peroxidase production by ligninolytic organisms, predominantly, fungi [44-46]. In this study, the effect of supplementing the production medium with $1 \mathrm{mM}$ of different lignin monomers (Guaiacol-GA, Veratryl alcohol-VALC, vanillin-VAN, vanillic acid-VA and ferullic acid-FA) on exoperoxidase production was assessed and the results are shown in Figure 2a. The results revealed there was a significant difference in peroxidase production by Ensifer adhaerens NWODO-2 grown in fermentation media supplemented with the different lignin monomers ( $\mathrm{F}=1023, p$ value $=p<0.0001$ for ANOVA). Also, Tukey's test showed that supplementation of the fermentation medium with guaiacol increased peroxidase production (AL + $\mathrm{GA}=5.25 \pm 0.00 \mathrm{U} \mathrm{mL}^{-1}$ ) by the bacteria when compared with the non-supplemented fermentation medium (AL), which served as the control $\left(\mathrm{AL}=2.10 \pm 0.00 \mathrm{U} \mathrm{mL}^{-1}\right)$. However, the difference in peroxidase production when the test bacteria was cultivated in a fermentation medium supplemented with veratryl alcohol $\left(\mathrm{AL}+\mathrm{VALC}=2.10 \pm 0.1 \mathrm{U} \mathrm{mL}^{-1}\right)$ was not significant when compared with the control: non-supplemented fermentation medium (AL) in a Tukey's test. Our findings showed that guaiacol induced peroxidase production in Ensifer adhaerens NWODO-2 as it increased the enzyme production by about $50 \%$ (Figure $2 \mathrm{a}$ ). On the other hand, veratryl alcohol did not induce peroxidase production in the test organism while vanillin, vanillic acid and ferulic acid seemed to promote repression of the enzyme synthesis. This finding is consistent with our recent study [25], where guaiacol was also reported as the best peroxidase inducer in Raoultella ornithinolytica but contrary to the findings of Musengi et al. [12], where veratryl alcohol produced the best peroxidase-inducing effect in Streptomyces sp. strain BSII\#1. Hence, inducers may be species-specific.

The influence of type and concentration of nitrogen sources on secretion of LMEs have been extensively studied, especially in fungi [47-49] but the findings are not always consistent [32]. Production media with adequate amount of nitrogen have improved the production of LMEs in some fungi [50]. More so, nitrogen-limited conditions have enhanced ligninolytic enzyme production [51-53] while in some cases, production of LMEs has been hampered by increased level of nitrogen [54]. The results from this study as presented in Figure $2 b$ revealed there was a significant difference ( $\mathrm{F}=17,940, p$ value $=p<0.0001$ for ANOVA) in peroxidase production by Ensifer adhaerens NWODO-2 cultivated in fermentation media supplemented with different inorganic nitrogen, with ammonium sulphate (YE + Ammonium sulphate) giving the maximum peroxidase production $(11.31 \pm 0.12 \mathrm{U}$ $\mathrm{mL}^{-1}$ ). Moreover, Tukey's multiple comparison test showed that augmentation of the production medium with various inorganic nitrogen (ammonium nitrate; ammonium chloride; and ammonium sulphate) significantly increased peroxidase production by Ensifer adhaerens NWODO-2 when compared with non-supplemented fermentation medium used as the control $\left(\mathrm{YE}=4.67 \pm 0.00 \mathrm{U} \mathrm{mL}^{-1}\right)$. This finding contradicts the result obtained by Falade et al. [25], where supplementation of yeast 
extract with ammonium chloride supported optimum extracellular peroxidase activity by Raoultella ornithinolytica OKOH-1.

(a)

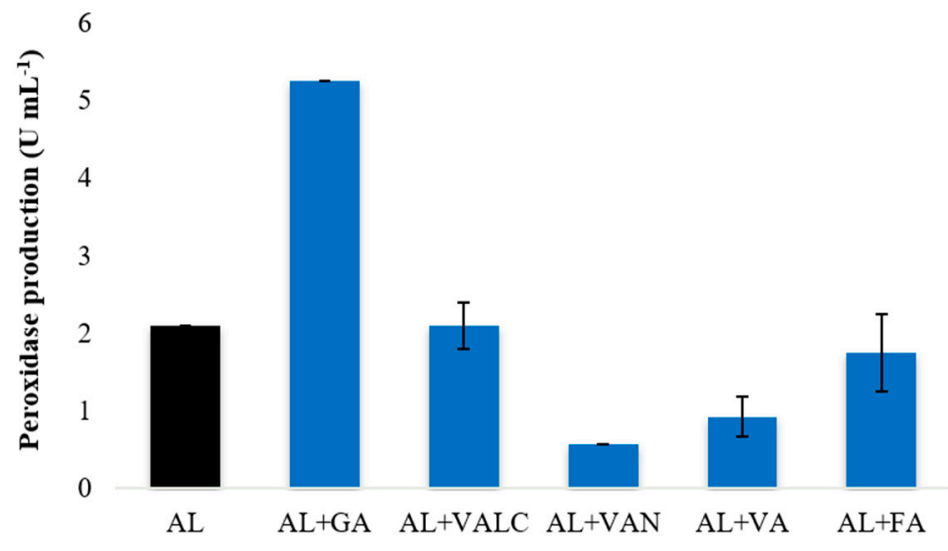

Lignin monomers

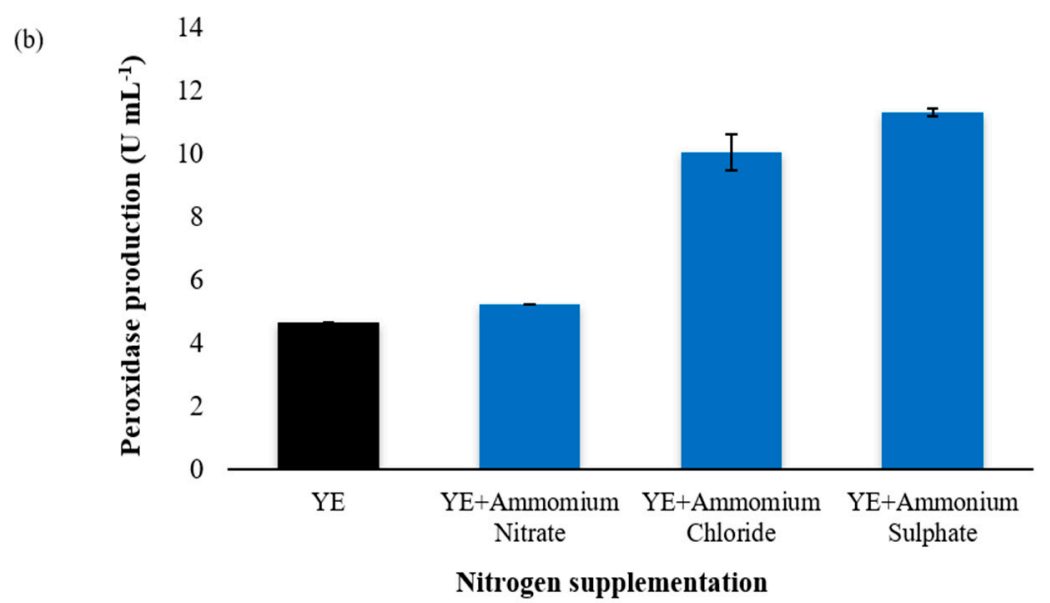

Figure 2. Effect of lignin monomers and nitrogen supplementations on exoperoxidase production by Ensifer adhaerens NWODO-2. (a) Effect of lignin monomers on exoperoxidase production. AL: alkali lignin (Control), GA: guaiacol, VALC: veratryl alcohol, VAN: vanillin, VA: vanillic acid, FA: ferulic acid. Analysis of variance: $\mathrm{F}=1023, p$ value $=p<0.0001, p$ value summary $=^{* * *}$ (highly significant), $\mathrm{R}$ squared $=0.9988$. (b) Effect of nitrogen supplementations on exoperoxidase production. YE: Yeast Extract (Control). Analysis of variance: $\mathrm{F}=17940, p$ value $=p<0.0001, p$ value summary ${ }^{* * *}$ (highly significant), R squared $=0.9999$.

\subsection{Exoperoxidase Production Over a Time Course}

The Ensifer strain was evaluated for extracellular enzyme production with and without hydrogen peroxide for $144 \mathrm{~h}$ and the findings are shown in Figure 3. The findings showed that Ensifer adhaerens NWODO-2 attained optimum peroxidase production $\left(12.19 \pm 1.05 \mathrm{U} \mathrm{mL}^{-1}\right)$ at $48 \mathrm{~h}$, corresponding to the late logarithmic growth phase with specific productivity of $12.76 \pm 1.09 \mathrm{U} \mathrm{mg}^{-1}$ (Figure 3a,b). However, there was a decline in exoperoxidase production as from $72 \mathrm{~h}$, which corresponds to the early stationary phase. More so, exoenzyme activity $\left(23.10 \pm 0.82 \mathrm{U} \mathrm{mL}^{-1}\right)$ was detected without the use of hydrogen peroxide and was optimal at $72 \mathrm{~h}$, with specific productivity of $12.76 \pm 0.45 \mathrm{U} \mathrm{mg}^{-1}$ protein (Figure 3a,b). The production of peroxidase by Ensifer adhaerens NWODO-2 is growth-associated as the enzyme activity increased significantly at the logarithmic phase with optimum productivity attained at $48 \mathrm{~h}$ (Figure 3). The sharp decrease in peroxidase production at $72 \mathrm{~h}$ may probably be associated with nutrient depletion or proteolytic activities $[22,55]$. This finding is contradictory to previous related 
reports, where optimal production of peroxidase by other bacteria species was achieved at $72 \mathrm{~h}$ of incubation $[23,35,36]$. This discrepancy may be a result of bacterial growth rate, culture medium and inoculum size. The detection of an extracellular enzyme activity without the use of hydrogen peroxide, the typical peroxidase activator, is noteworthy as this may suggest probable laccase production by Ensifer adhaerens NWODO-2 [25].

(a)

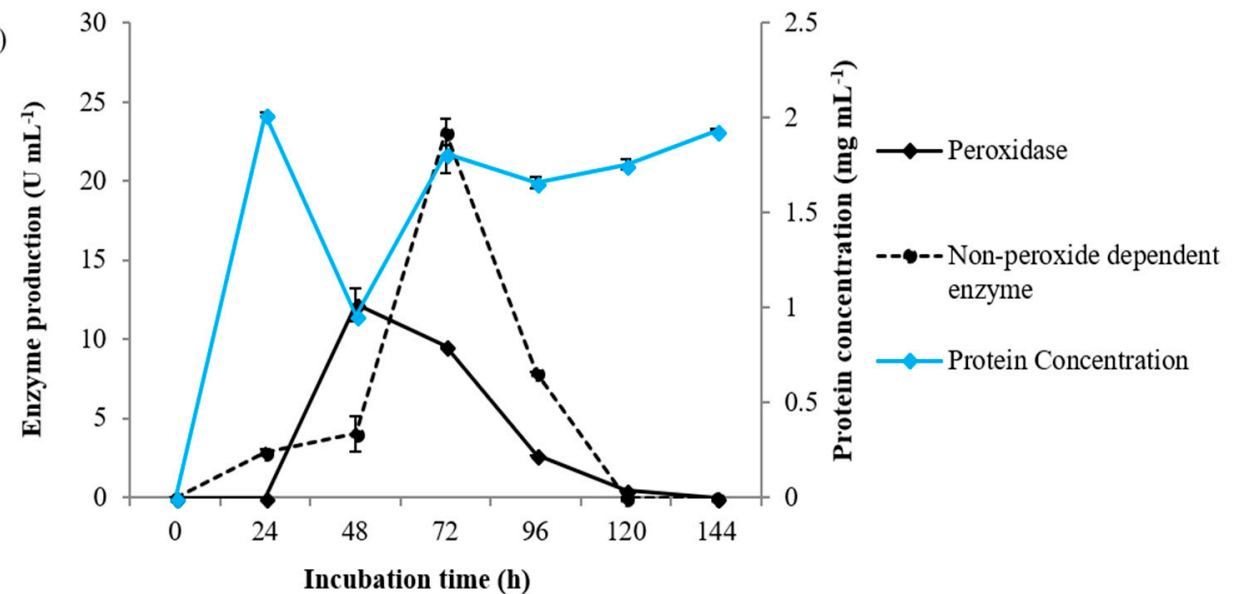

(b)

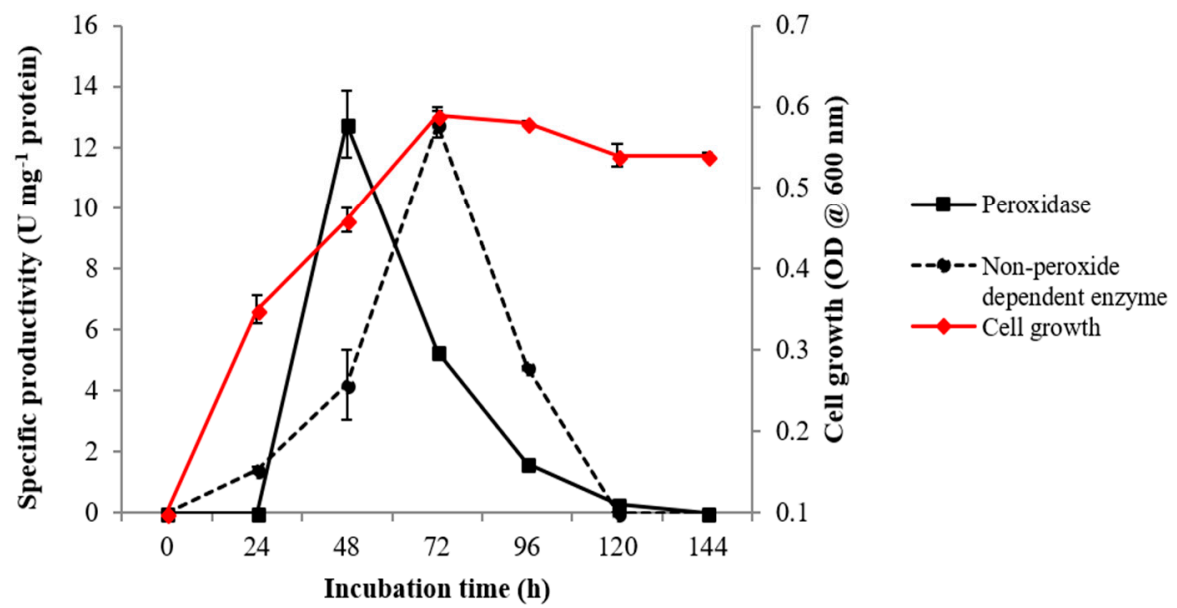

Figure 3. Exoperoxidase production by Ensifer adhaerens NWODO-2 over a time course. (a) Enzyme production and protein concentration. (b) Specific productivity and cell growth.

\subsection{Assessment of Agricultural Residues for Exoperoxidase Production}

The high cost of production is a major challenge to the industrial application potentials of peroxidases. Hence, it is imperative to find cost-effective means of peroxidase production. The use of cheap substrates as alternative carbon sources for fermentation has been suggested as an efficient means of reducing enzyme production cost [56]. The abundance, availability and renewable nature of lignocellulosic materials confer on them the status of perfect candidates of cheap carbon sources. Agro-residues including sawdust, wheat straw, corn cobs, rice straw, peapods etc have been utilized for production of various lignocellulolytic enzymes through solid state and submerged fermentation processes [25,57-60]. However, SSF is perhaps, more promising for optimum utilization of agricultural residues for enzyme production as SSF is reported to be economical [61]. SSF is also characterized by high yield, low wastewater output and decrease in energy demand [62]. This study assessed selected agricultural residues (sawdust, wheat straw and corn stover) for peroxidase production by Ensifer adhaerens NWODO-2 under SSF and the results are presented in Table 1. 
Table 1. Utilization of some agricultural residues for exoperoxidase production by Ensifer adhaerens NWODO-2.

\begin{tabular}{|c|c|c|c|c|c|}
\hline \multirow[b]{2}{*}{$\begin{array}{l}\text { Agricultural } \\
\text { Residue }\end{array}$} & \multirow[b]{2}{*}{$\begin{array}{c}\text { Protein } \\
\text { Concentration } \\
\left(\mathrm{mg} \mathrm{mL}^{-1}\right)\end{array}$} & \multicolumn{2}{|c|}{ Enzyme Assay (With $\mathrm{H}_{2} \mathrm{O}_{2}$ ) } & \multicolumn{2}{|c|}{ Enzyme Assay (Without $\mathrm{H}_{2} \mathrm{O}_{2}$ ) } \\
\hline & & $\begin{array}{c}\text { Peroxidase } \\
\text { Production } \\
\left(\mathrm{U} \mathrm{mL}^{-1}\right)\end{array}$ & $\begin{array}{c}\text { Specific } \\
\text { Productivity } \\
\left(\mathrm{U} \mathrm{mg}^{-1}\right)\end{array}$ & $\begin{array}{l}\text { Probable } \\
\text { Laccase } \\
\text { Production } \\
\left(\mathrm{U} \mathrm{mL}^{-1}\right)\end{array}$ & $\begin{array}{c}\text { Specific } \\
\text { Productivity } \\
\left(\mathrm{U} \mathrm{mg}^{-1}\right)\end{array}$ \\
\hline Sawdust & $0.028 \pm 0.0^{a}$ & $1.05 \pm 0.00^{\mathrm{a}}$ & $37.50 \pm 0.00^{a}$ & NAD* & NAD* \\
\hline Wheat Straw & $1.023 \pm 0.116^{b}$ & $5.37 \pm 0.00^{b}$ & $5.25 \pm 0.00^{b}$ & NAD * & NAD * \\
\hline Corn Stover & $1.366 \pm 0.021^{b}$ & $5.13 \pm 0.00^{b}$ & $3.76 \pm 0.00^{\mathrm{c}}$ & $1.93 \pm 0.53$ & $1.23 \pm 0.21$ \\
\hline
\end{tabular}

NAD *-No Activity Detected. Values with the same superscript letter along the same column are not significantly different $(p>0.05)$.

The results revealed that peroxidase production by the test organism differ significantly $(p<$ $0.05)$ when cultivated on the different substrates, with sawdust supporting the highest production $\left(37.50 \pm 0.00 \mathrm{U} \mathrm{mg}^{-1}\right)$ while the lowest production was recorded with corn stover $\left(3.76 \pm 0.00 \mathrm{U} \mathrm{mg}^{-1}\right)$. This result is in agreement with previous similar investigations [25,57,63], where high peroxidase activity was induced by sawdust as solid substrate under SSF. This finding could be linked to the inductive effect of the phenolic and non-phenolic constituents of sawdust. Nonetheless, enzyme activity was not detected in the absence of hydrogen peroxide when grown on sawdust and wheat straw but a specific extracellular enzyme activity of $1.23 \pm 0.21 \mathrm{U} \mathrm{mg}^{-1}$ was detected in the absence of hydrogen peroxide when grown on corn stover. The extracellular enzyme activity observed in the absence of hydrogen peroxide when Ensifer adhaerens NWODO-2 was grown on corn stover indicates likely laccase production. This suggests that corn stover may possess phenolic compounds with inductive laccase effect $[64,65]$.

\subsection{PCR Detection of Peroxidase Gene}

Molecular optimization and genetic engineering seem to be the best option for increased enzyme production. Hence, the imperativeness of detecting the gene responsible for the expression of the enzyme of interest in an organism. Figure 4a shows the gel picture of the PCR amplified product from Ensifer adhaeren NWODO-2. The results showed the band size of the amplified gene as $800 \mathrm{bp}$. The search of the nucleotide sequence in the UniProt Knowledgebase using blastx program showed $70.5 \%$ similarity to Ensifer adhaerens uncharacterized protein (ANK75658). However, phylogenetic analysis of the expressed protein sequence and selected bacterial heme peroxidases in the PeroxiBase database (peroxibase.toulouse.inra.fr) showed that it clustered with catalase-peroxidases (Figure 4b). This finding suggests that the amplified gene from Ensifer adhaerens NWODO-2 may encode a novel catalase-peroxidase with an estimated molecular weight of approximately $31 \mathrm{kDa}$ and isoelectric point of about 11. Bacterial catalase-peroxidases $(\mathrm{KatG})$ belong to class I peroxidases of the peroxidase-catalase superfamily of heme-peroxidases [66]. Other members of class I peroxidases include yeast cytochrome c peroxidases and ascorbate peroxidases.

The KatG gene encodes the expression of both catalase and peroxidase activity [67] in an organism. This therefore suggests that peroxidase activity expressed in Ensifer adhaerens NWODO-2 may be attributed to the presence of the KatG gene in the new bacteria strain. Hence, the gene could be explored for large scale production of catalase and peroxidase through genetic engineering, which has proven difficult in fungi [15]. Apart from the fact that the KatG gene encodes peroxidase activity, bacteria catalase-peroxidases have recently been implicated in the degradation of lignocellulose $[68,69]$. Therefore, the presence of the KatG gene in Ensifer adhaerens NWODO-2 further attests to its ligninolytic potential, which was previously reported by the authors [14]. 
(a)

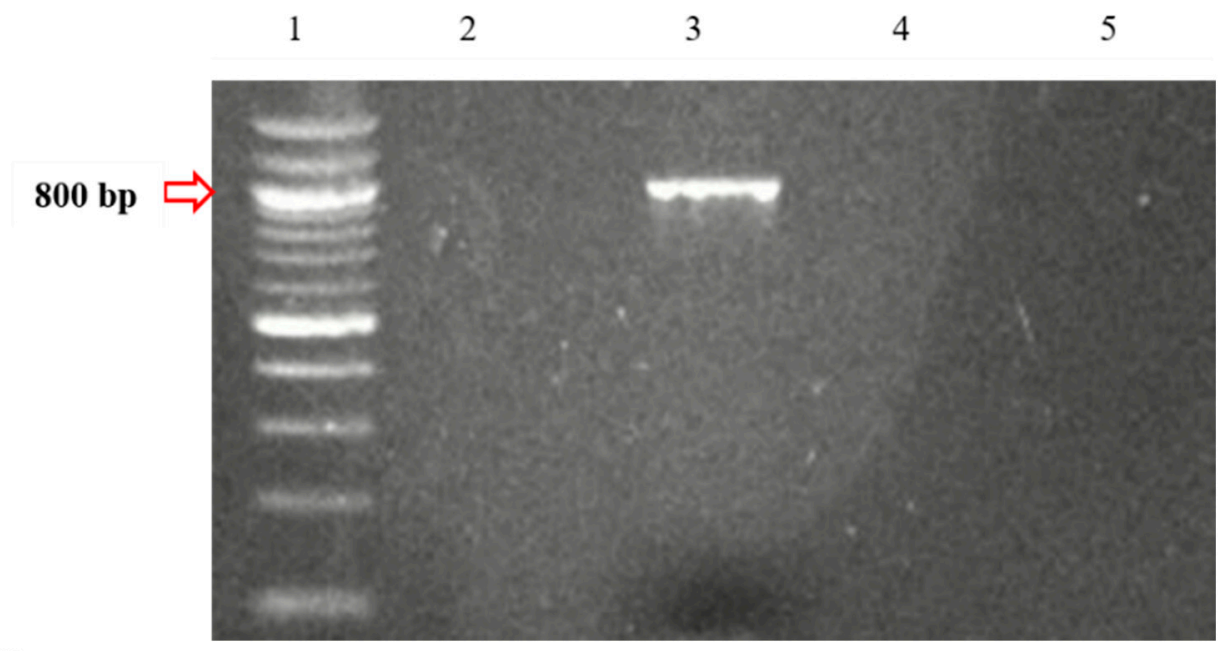

(b)

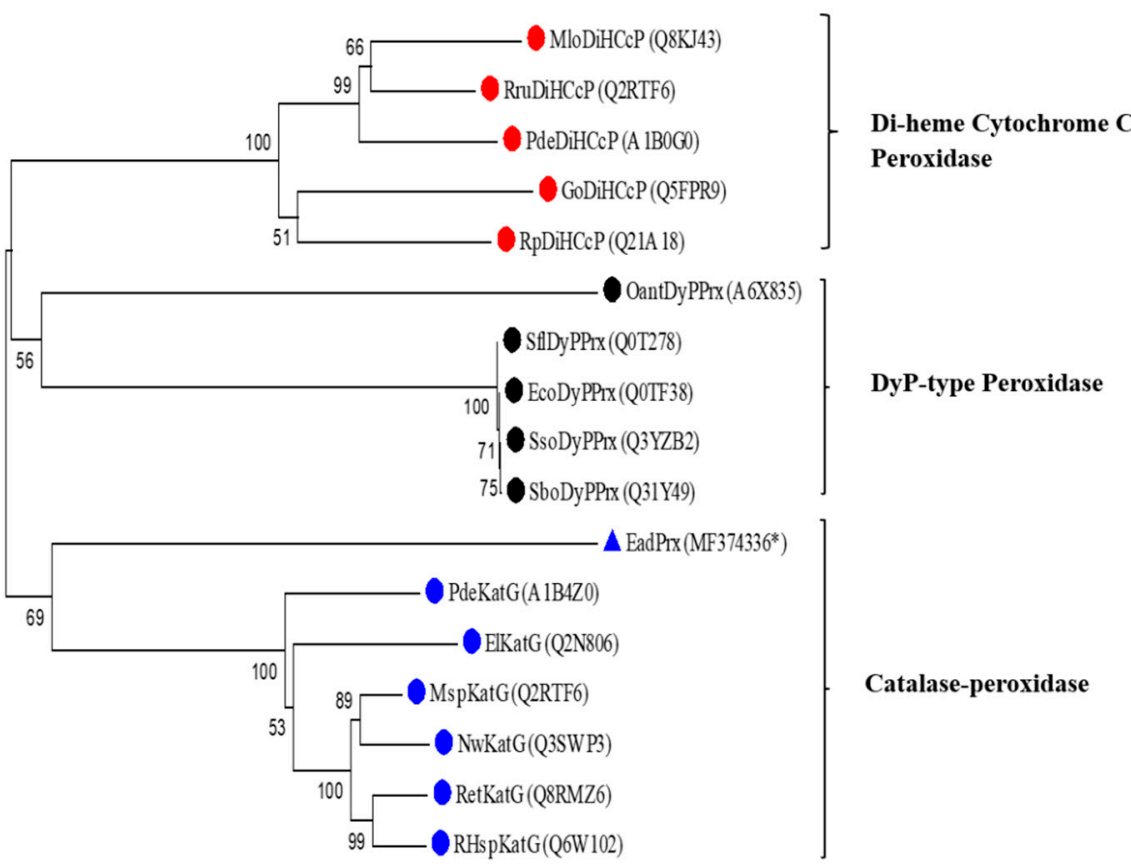

0.2

Figure 4. Molecular characterization of peroxidase in Ensifer adhaerens NWODO-2. (a) Gel picture of the polymerase chain reaction (PCR)-amplified product. Lane 1:100 bp DNA ladder, lane 2: Empty, lane 3: PCR-amplified product from Ensifer adhaerens NWODO-2, lane 4: Negative control. (b) Unrooted phylogenetic tree showing the relationship of Ensifer adhaerens NWODO-2 peroxidase with selected bacterial heme-peroxidases in the PeroxiBase. The percentage of replicate trees in which the associated taxa clustered together in the bootstrap test (1000 replicates) are shown next to the branches. Red tips indicate Di-heme cytochrome $\mathrm{C}$ peroxidase ( $\mathrm{DiHCcP}$ ) family, black tips indicate DyP-type peroxidase family, while the blue tips represent catalase-peroxidases. The blue triangular tip indicates the protein sequence obtained in this study (EadPrx). The UniProtKB reference numbers/GenBank accession number* of the proteins are indicated in parentheses. El: Erythrobacter litoralis, Msp: Mesorhizobium sp., Nw: Nitrobacter winogradskyi, Pde: Paracoccus denitrificans, Ret: Rhizobium etli, RHsp: Rhizobium sp., Mlo: Mesorhizobium loti, Rp: Rhodopseudomonas palustris, Rru: Rhodospirillum rubrum, Go: Gluconobacter oxydans, Eco: Escherichia coli, Sbo: Shigella boydii, Sso: Shigella sonnei, Sf: Shigella flexneri, Oant: Ochrobactrum anthropic, EadPrx: Ensifer adhaerens NWODO-2 peroxidase, DyPPrx: dye-decolourizing peroxidase, KatG: catalase-peroxidase. 


\section{Conclusions}

Peroxidase production by Ensifer adhaerens NWODO-2 was optimal at a neutral $\mathrm{pH}$, mesophilic temperature, mild agitation rate and relatively short incubation time. In this study, peroxidase production increased by over $100 \%$ under optimal conditions with guaiacol as an inducer and sawdust as the best substrate for solid state fermentation. The ability of the new strain to utilize agricultural residues as cheap renewable substrates for peroxidase production serve as an economical means of enzyme production, which could be employed for large-scale production and consequent biotechnological applications. Furthermore, a novel catalase-peroxidase encoding gene detected in Ensifer adhaerens NWODO-2 may be responsible for the peroxidase activity expressed in the organism.

Author Contributions: Conceptualization, A.F., A.J., L.M., A.O. and U.N.; formal analysis, A.F.; data curation, A.F.; writing—original draft preparation, A.F.; writing-review and editing, A.J., L.M., A.O. and U.N.; supervision, L.M., A.O. and U.N.; project administration, A.J., L.M., A.O. and U.N.; funding acquisition, A.J., L.M., A.O. and U.N.

Funding: This research was funded by the National Research Foundation (NRF), South Africa [grant number: 95364] and South African Medical Research Council (SAMRC). Prof Atef Jaouani wants to thank the Tunisian Ministry of Higher Education and Scientific Research for funding the cooperation project with the South African partners.

Acknowledgments: The authors thank Olufemi Obameso who designed the primers for this study.

Conflicts of Interest: The authors declare no conflict of interest.

\section{Abbreviations}

$\begin{array}{ll}\text { AL } & \text { alkali lignin } \\ \text { ALM } & \text { alkali lignin medium } \\ \text { ANOVA } & \text { analysis of variance } \\ \text { BLAST } & \text { basic local alignment search tool } \\ \text { FA } & \text { ferulic acid } \\ \text { GA } & \text { guaiacol } \\ \text { LMEs } & \text { lignin modifying enzymes } \\ \text { MEGA } & \text { molecular evolutionary genetics analysis } \\ \text { NAD } & \text { not detected } \\ \text { NCBI } & \text { National Center for Biotechnology Information } \\ \text { OD } & \text { optical density } \\ \text { SMF } & \text { submerged fermentation } \\ \text { SSF } & \text { solid state fermentation } \\ \text { UV } & \text { ultraviolet } \\ \text { VALC } & \text { veratryl alcohol } \\ \text { VAN } & \text { vanillin } \\ \text { VA } & \text { vanillic acid }\end{array}$

\section{References}

1. Draelos, Z.D. A split-face evaluation of a novel pigment-lightening agent compared with no treatment and hydroquinone. J. Am. Acad. Dermatol. 2015, 72, 105-107. [CrossRef] [PubMed]

2. Taboada-Puig, R.; Lu-Chau, T.A.; Eibes, G.; Feijoo, G.; Moreira, M.T.; Lema, J.; Taboada-Puig, R.; Lú-Chau, T.A. Continuous removal of endocrine disruptors by versatile peroxidase using a two-stage system. Biotechnol. Proc. 2015, 31, 908-916. [CrossRef] [PubMed]

3. Ferrer, I.; Dezotti, M.; Duran, N. Decolourisation of kraft effluent by free and immobilised lignin peroxidases and horseradish peroxidase. Biotechnol. Lett. 1991, 13, 577-582. [CrossRef]

4. Torres, E.; Bustos-Jaimes, I.; Le Borgne, S. Potential use of oxidative enzymes for the detoxification of organic pollutants. Appl. Catal. B Environ. 2003, 46, 1-15. [CrossRef] 
5. Valderrama, B.; Ayala, M.; Vasquez-Duhalt, R. Suicide inactivation of peroxidases and the challenge of engineering more robust enzymes. Chem. Biol. 2002, 9, 555-565. [CrossRef]

6. Ikehata, K.; Pickard, M.A.; Buchanan, I.D.; Smith, D.W. Optimization of extracellular fungal peroxidase production by 2 Coprinus species. Can. J. Microbiol. 2004, 50, 1033-1040. [CrossRef]

7. Urek, R.O.; Pazarlioglu, N.K. Enhanced production of manganese peroxidase by Phanerochaete chrysosporium. Braz. Arch. Biol. Technol. 2007, 50, 913-920. [CrossRef]

8. Hariharan, S.; Nambisan, P. Optimization of lignin peroxidase, manganese peroxidase and lac production from Ganoderma lucidum under solid state fermentation of pineapple leaf. BioResources 2013, 8, 250-271. [CrossRef]

9. Mercer, D.K.; Iqbal, M.; Miller, P.G.G.; McCarthy, A.J. Screening actinomycetes for extracellular peroxidase activity. Appl. Environ. Microbiol. 1996, 62, 2186-2190.

10. Tuncer, M.; Kuru, A.; Isikli, M.; Sahin, N.; Çelenk, F. Optimization of extracellular endoxylanase, endoglucanase, and peroxidase production by Streptomyces sp. F2621 isolated in Turkey. J. Appl. Microbiol. 2004, 97, 783-791. [CrossRef]

11. Tuncer, M.; Kuru, A.; Sahin, N.; Isikli, M. Production and partial characterisation of extracellular peroxidase produced by Streptomyces sp. F6616 isolated in Turkey. Ann. Microbiol. 2009, 59, 323-334. [CrossRef]

12. Musengi, A.; Khan, N.; Le Roes-Hill, M.; Pletschke, B.I. Increasing the scale of peroxidase production by Streptomyces sp. strain BSII\#1. J. Appl. Microbiol. 2014, 116, 554-562. [PubMed]

13. Anbu, P.; Gopinath, S.C.B.; Cihan, A.C.; Chaulagain, B.P. Microbial enzymes and their applications in industries and medicine. BioMed. Res. Int. 2017. [CrossRef] [PubMed]

14. Falade, A.O.; Eyisi, O.A.L.; Mabinya, L.V.; Nwodo, U.U.; Okoh, A.I. Peroxidase production and ligninolytic potentials of freshwater bacteria Raoutella ornithinolytica and Ensifer adhaerens. Biotechnol. Rep. 2017, 16, $12-17$. [CrossRef]

15. Bugg, T.D.H.; Ahmad, M.; Hardiman, E.M.; Singh, R. The emerging role for bacteria in lignin degradation and bio-product formation. Curr. Opin. Biotechnol. 2011, 22, 394-400. [CrossRef] [PubMed]

16. Taylor, C.; Hardiman, E.; Ahmad, M.; Sainsbury, P.; Norris, P.; Bugg, T. Isolation of bacterial strains able to metabolize lignin from screening of environmental samples. J. Appl. Microbiol. 2012, 113, 521-530. [CrossRef] [PubMed]

17. Prabhakaran, M.; Couger, M.B.; Jackson, C.A.; Weirick, T.; Fathepure, B.Z.; Lopez-Alonso, V.; Ortiz, S.; Martínez-Suárez, J.V. Genome sequences of the lignin-degrading Pseudomonas sp. strain YS-1p and Rhizobium sp. strain YS-1r isolated from decaying wood. Genome Announc. 2015, 3, e00019-15. [CrossRef]

18. Woo, H.L.; Utturkar, S.; Klingeman, D.; Simmons, B.A.; DeAngelis, K.M.; Brown, S.D.; Hazen, T.C. Draft genome sequence of the lignin-degrading Burkholderia sp. strain LIG30 isolated from wet tropical forest soil. Genome Announc. 2014, 2, e00637-14. [CrossRef]

19. Kalyani, D.C.; Phugare, S.S.; Shedbalkar, U.U.; Adhar, J.P. Purification and characterization of a bacterial peroxidase from the isolated strain Pseudomonas sp. SUK1 and its application for textile dye decolourization. Ann. Microbiol. 2011, 61, 483-491. [CrossRef]

20. Sasikumar, V.; Priya, V.; Shiv, S.C.; Sathish, S.D. Isolation and preliminary screening of lignin degrading microbes. J. Acad. Indus. Res. 2014, 3, 291-294.

21. Chance, B.; Maehly, A.C. Assay of catalases and peroxidases. Methods Enzymol. 1955, 2, 773-775.

22. Fatokun, E.N.; Nwodo, U.U.; Okoh, A.I. Classical optimization of cellulase and xylanase production by a marine Streptomyces species. Appl. Sci. 2016, 6, 286. [CrossRef]

23. Tuncer, M.; Rob, A.; Ball, A.S.; Wilson, M.T. Optimisation of extracellular lignocellulolytic enzyme production by a thermophilic actinomycete Thermomonospora fusca BD25. Enzym. Microb. Technol. 1999, 25, 38-47. [CrossRef]

24. Bradford, M.M. A rapid and sensitive method for the quantitation of microgram quantities of protein utilizing the principle of protein-dye binding. Anal. Biochem. 1976, 72, 248-254. [CrossRef]

25. Falade, A.O.; Mabinya, L.V.; Okoh, A.I.; Nwodo, U.U. Agrowastes utilization by Raoultella ornithinolytica for optimal extracellular peroxidase activity. Biotechnol. Appl. Biochem. 2019, 66, 60-67. [CrossRef] 
26. Neifar, M.; Chouchane, H.; Mahjoubi, M.; Jaouani, A.; Cherif, A. Pseudomonas extremorientalis BU118: A new salt-tolerant laccase-secreting bacterium with biotechnological potential in textile azo dye decolourization. 3 Biotech 2016, 6, 107-115. [CrossRef] [PubMed]

27. Maugeri, T.L.; Carbone, M.; Tera, M.T.; Gugliandolo, C. Detection and differentiation of Vibrio vulnificus in seawater and plankton of a coastal zone of the Mediterranean Sea. Res. Microbiol. 2006, 157, 194-200. [CrossRef]

28. Falade, A.O.; Mabinya, L.V.; Okoh, A.I.; Nwodo, U.U. Biochemical and molecular characterization of a novel dye-decolourizing peroxidase from Raoultella ornithinolytica OKOH-1. Int. J. Biol. Macromol. 2019, 121, 454-462. [CrossRef]

29. Saitou, N.; Nei, M. The neighbor-joining method: A new method for reconstructing phylogenetic trees. Mol. Biol. Evol. 1987, 4, 406-425.

30. Kumar, S.; Stecher, G.; Tamura, K. MEGA7: Molecular evolutionary genetics analysis version 7.0 for bigger datasets. Mol. Biol. Evol. 2016, 33, 1870-1874. [CrossRef]

31. McCarthy, A.J. Lignocellulose degrading actinomycetes. FEMS Microbiol. Rev. 1987, 46, 145-163. [CrossRef]

32. Niladevi, K.N.; Prema, P. Effect of inducers and process parameters on laccase production by Streptomyces psammoticus and its application in dye decolourization. Bioresour. Technol. 2008, 99, 4583-4589. [CrossRef] [PubMed]

33. Salehizadeh, H.; Shojaosadati, S.A. Extracellular biopolymeric flocculants: Recent trends and biotechnological importance. Biotechnol. Adv. 2001, 19, 371-385. [CrossRef]

34. Makapela, B.; Okaiyeto, K.; Ntozonke, N.; Nwodo, U.U.; Green, E.; Mabinya, L.; Okoh, A. Assessment of Bacillus pumilus isolated from freshwater milieu for bioffloculant production. Appl. Sci. 2016, 6, 211. [CrossRef]

35. Rob, A.; Hernandez, M.; Ball, A.S.; Tuncer, M.; Arias, M.E.; Wilson, M.T. Production and partial characterization of extracellular peroxidase produced by Streptomyces avermitilis UAH30. Appl. Biochem. Biotechnol. 1997, 62, 159-174. [CrossRef]

36. Nour El-Dein, M.M.; Shereif, A.E.A.; Mansour, F.A.; Abou-Dobara, M.I.; Ball, A.S. Optimization of xylanase and peroxidase production from Streptomyces sp. K37. J. BioSci. Biotechnol. 2014, 3, $29-42$.

37. Xia, S.Q.; Zhang, Z.Q.; Wang, X.J.; Yang, A.M.; Chen, L.; Zhao, J.; Leonard, D.; Jaffrezic-Renault, N. Production and characterization of a bioffloculant by Proteus mirabilis TJ-1. Bioresour. Technol. 2008, 99, 6520-6527. [CrossRef]

38. Rajkumar, R.; Yaakob, Z.; Takriff, M.S.; Kamarudin, K.F. Optimization of medium composition for production of peroxidase by Bacillus sp. Der Pharma Chem. 2013, 5, 167-174.

39. Rao, P.R.; Kavya, P. Production, isolation and purification of peroxidase using Bacillus subtilis. 2014 1st International Congress on Environmental, Biotechnology, and Chemistry Engineering. Int. Cong. Environ. Biotechnol. Chem. Eng. 2014, 64, 21-27.

40. Ray, A.K.; Bairagi, A.; Ghosh, K.S.; Sen, S.K. Optimization of fermentation conditions for cellulase production by Bacillus subtilis CY5 and Bacillus circulans TP3 isolated from fish gut. Acta Ichthyol. Piscat. 2007, 3, 47-53. [CrossRef]

41. Giavasis, I.; Harvey, L.M.; McNeil, B. The effect of agitation and aeration on the synthesis and molecular weight of gellan in batch cultures of Sphingomonas paucimobilis. Enzym. Microb. Technol. 2006, 38, 101-108. [CrossRef]

42. Sepahy, A.A.; Ghazi, S.; Sepahy, M.A. Cost-effective production and optimization of alkaline xylanase by indigenous Bacillus mojavensis AG137 fermented on waste. Enzym. Res. 2011, 593624. [CrossRef]

43. Patil, S.R. Production and purification of lignin peroxidase from Bacillus megaterium and its application in bioremediation. CIB Tech J. Microbiol. 2014, 3, 22-28.

44. Niku-Paavola, M.-L.; Karhunen, E.; Kantelinen, A.; Viikari, L.; Lundell, T.; Hatakka, A. The effect of culture conditions on the production of lignin modifying enzymes by the white rot fungus Phlebia radiata. J. Biotechnol. 1990, 13, 211-221. [CrossRef]

45. Mester, T.; de Jong, E.; Field, J.A. Manganese regulation of veratryl alcohol in white rot fungi and its indirect effect of lignin peroxidase. Appl. Environ. Microbiol. 1995, 61, 1881-1887. [PubMed]

46. Couto, S.R.; Longo, M.A.; Cameselle, C.; Sanromán, A. Ligninolytic enzymes from corncob cultures of Phanerochaete chrysosporium under semi-solid-state conditions. Acta Biotechnol. 1999, 19, 17-25. [CrossRef] 
47. Kachlishvili, E.; Penninck, M.J.; Tsiklauri, N.; Elisashvili, V. Effect of nitrogen source on lignocellulolytic enzyme production by white-rot basidiomycetes under solid state cultivation. World J. Microbiol. Biotechnol. 2005, 22, 391-397. [CrossRef]

48. Mikiashvili, N.; Wasser, S.P.; Nevo, E.; Elisashvili, V. Effects of carbon and nitrogen sources on Pleurotus ostreatus ligninolytic enzyme activity. World J. Microbiol. Biotechnol. 2006, 22, 999-1002. [CrossRef]

49. Stajic, M.; Persky, L.; Friesem, D.; Hadar, Y.; Wasser, S.P.; Nevo, E.; Vukojević, J. Effect of different carbon and nitrogen sources on laccase and peroxidases production by selected Pleurotus species. Enzym. Microb. Technol. 2006, 38, 65-73. [CrossRef]

50. Kaal, E.E.J.; Field, J.A.; Joyce, T.W. Increasing ligninolytic enzyme activities in several white-rot basidiomycetes by nitrogen sufficient media. Bioresour. Technol. 1995, 53, 133-139. [CrossRef]

51. Mester, T.A.; Field, A.J. Optimization of manganese peroxidase production by the white-rot fungus Bjerkandera sp. strain BOS55. FEMS Microbiol. Lett. 1997, 155, 161-168. [CrossRef]

52. Gianfreda, L.; Xu, F.; Bollag, J. Laccases: A useful group of oxidoreductive enzymes. Bioremediat. J. 1999, 3, 1-25. [CrossRef]

53. Galhaup, C.; Wagner, H.; Hinterstoisser, B.; Haltrich, D. Increased production of laccase by the wood-degrading basidiomycete Trametes pubescens. Enzym. Microb. Technol. 2002, 30, 529-536. [CrossRef]

54. Buswell, J.A. Fungal degradation of lignin. In Handbook of Applied Mycology; Arora, D.K., Rai, B., Mukerji, K.G., Kundsen, G., Eds.; Marcel Dekker: New York, NY, USA, 1992; pp. 425-480.

55. Papagianni, M.; Moo-Young, M. Protease secretion in glucoamylase producer Aspergillus niger cultures: Fungal morphology and inoculum effects. Process Biochem. 2002, 37, 1271-1278. [CrossRef]

56. Falade, A.O.; Nwodo, U.U.; Iweriebor, B.C.; Green, E.; Mabinya, L.V.; Okoh, A.I. Lignin peroxidase functionalities and prospective applications. Microbiologyopen 2017, 6, e00394. [CrossRef]

57. Knezevic, A.; Milovanovic, I.; Stajic, M.; Vakojevic, J. Trametes suaveolens as ligninolytic enzyme producer. J. Nat. Sci. 2013, 124, 437-444. [CrossRef]

58. Saratale, G.D.; Kshirsagar, S.D.; Sampange, V.T.; Saratale, R.G.; Oh, S.-E.; Govindwar, S.P.; Oh, M.-K. Cellulolytic enzymes production by utilizing agricultural wastes under solid state fermentation and its application for biohydrogen production. Appl. Biochem. Biotechnol. 2014, 174, 2801-2817. [CrossRef]

59. Sharma, R.; Rawat, R.; Bhogal, R.S.; Oberoi, H.S. Multi-component thermostable cellulolytic enzyme production by Aspergillus niger $\mathrm{HN}-1$ using pea pod waste: Appraisal of hydrolytic potential with lignocellulosic biomass. Process Biochem. 2015, 50, 696-704. [CrossRef]

60. Olajuyigbe, F.M.; Ogunyewo, O.A. Enhanced production and physicochemical properties of thermostable crude cellulose from Sporothrix carnis grown on corn cobs. Biocatal. Agric. Biotechnol. 2016, 7, $110-117$. [CrossRef]

61. Muthukumarasamy, N.; Murugan, S. Production, purification and application of bacterial laccase: A review. Biotechnol. Adv. 2014, 13, 196-205.

62. Niladevi, K.N.; Sukumaran, R.K.; Prema, P. Utilization of rice straw for laccase production by Streptomyces psammoticus in solid state fermentation. J. Ind. Microbiol. Biotechnol. 2007, 34, 665-674. [CrossRef] [PubMed]

63. Kamsani, N.; Salleh, M.M.; Yahya, A.; Chong, C.S. Production of lignocellulolytic enzymes by microorganisms isolated from Bulbitermes sp. termite gut in solid-state fermentation. Waste Biomass Valor. 2016, 7, 357. [CrossRef]

64. Unuofin, J.O.; Okoh, A.I.; Nwodo, U.U. Utilization of agricultural wastes for the production of laccase by Achromobacter xylosoxidans HWN16 and Bordetella bronchiseptica HSO16. J. Environ. Manag. 2019, 231, $222-231$. [CrossRef] [PubMed]

65. Unuofin, J.O.; Okoh, A.I.; Nwodo, U.U. Maize stover as a feedstock for enhanced laccase production by two gamma proteobacteria: A solution to agroindustrial waste stockpiling. Ind. Crop Prod. 2019, 129, 611-623. [CrossRef]

66. Zamocky, M.; Furtmuller, P.G.; Obinger, C. Evolution of catalases from bacteria to humans. Antioxid. Redox Signal. 2008, 10, 1527-1547. [CrossRef] [PubMed]

67. Zamocky, M.; Obinger, C. Molecular phylogeny of heme peroxidases. In Biocatalysis Based on Heme Peroxidases; Torres, E., Ayala, M., Eds.; Springer: Heidelberg, Germany, 2010; pp. 7-35. 
68. Brown, M.E.; Walker, M.C.; Nakashige, T.G.; Iavarone, A.T.; Chang, M.C.Y. Discovery and characterization of heme enzymes from unsequenced bacteria: Application to microbial lignin degradation. J. Am. Chem. Soc. 2011, 133, 18006-18009. [CrossRef] [PubMed]

69. De Gonzalo, G.; Colpa, D.I.; Habib, M.H.M.; Fraaije, M.W. Bacterial enzymes involved in lignin degradation. J. Biotechnol. 2016, 236, 110-119. [CrossRef]

(C) 2019 by the authors. Licensee MDPI, Basel, Switzerland. This article is an open access article distributed under the terms and conditions of the Creative Commons Attribution (CC BY) license (http://creativecommons.org/licenses/by/4.0/). 